\title{
Arthrotomy and Washing Procedure for Neonatal Bacterial Arthritis in a Series of Cases
}

\section{Bir Olgu Serisinde Yenidoğan Bakteriyel Artriti için Artrotomi ve Ylkama Prosedürü}

\author{
(D) Çağrı Cumhur Gök1, (D) Tuba Kılıçlar², (D) Emrah Can¹, (D) Şahin Hamilçıkan1 \\ ${ }^{1}$ University of Health Sciences Turkey, İstanbul Bağcılar Training and Research Hospital, Clinic of Neonatal Intensive Care, İstanbul, Turkey \\ ${ }^{2}$ University of Health Sciences Turkey, İstanbul Bağcllar Training and Research Hospital, Clinic of Pediatrics, İstanbul, Turkey
}

\section{Abstract}

Septic arthritis is a rare health issue during neonatal period. It should be remembered that the treatment of this disease can lead to serious problems in the long term when it is late. In this series of cases, we presented arthrotomy and washing procedures in three neonatal patients with septic arthritis. We evaluated the pros and cons of the procedure and we compared it to non-surgical treatment methods. We have concluded that the washing procedure can be more effective than nonsurgical methods.

Keywords: Arthritis, arthrotomy, neonate

\section{Öz}

Septik artrit, yenidoğan döneminde nadir görülen bir hastalıktır. Bu hastalığın tedavide geç kalındığında uzun vadede ciddi problemlere yol açabileceği unutulmamalıdır. Bu olgu serisinde septik artrit tanıı üç yenidoğan hastamıza artrotomi ve yıkama prosedürünün uygulamasını sunduk. Prosedürü kar zarar açısından değerlendirdik. Cerrahi olmayan yöntemlerle karşılaştırdık. Eklem yıkama prosedürünün cerrahi olmayan yöntemlerden daha etkili olabileceğini düşünmekteyiz.

Anahtar kelimeler: Artrit, artrotomi, yenidoğan

\section{Introduction}

Septic arthritis (SA) is an important condition for the neonates, which may cause permanent disability if left untreated. It is more important for neonates because early treatment may leave no complications but being late in treatment may cause permanent effect by damaging articular cartilage and causing osteonecrosis. Especially when the joints are weight-bearing, the consequences can be more catastrophic. It is also challenging to diagnose SA in neonates because the symptoms appear silently. If parents recognize most common symptoms such as grimace, crying and restlessness during diaper changing, they should apply to a hospital early. Open surgical drainage is recommended for bacterial arthritis of the hip in infants. Factors to be considered before the procedure include the site and extent of the joint involvement, duration of symptoms, and the suspected organism (1). Based on clinical reports, arthrotomy is the preferred procedure for bacterial arthritis of the shoulder in infants (2). We presented a case series of three neonates that had arthrotomy and surgical washout therapy for the treatment of SA and we obtained consent from the families of the cases.

\section{Case Reports}

\section{Case 1}

A 3.390-g male neonate was born by cesarean delivery, at 39 weeks of gestation to a 28 -year-old gravida 3 mother. The neonate was seen in the delivery room, and given to the

Address for Correspondence: Emrah Can, University of Health Sciences Turkey, İstanbul Bağcılar Training and Research Hospital, Clinic of Neonatal Intensive Care, İstanbul, Turkey

E-mail: canemrahcan@yahoo.com ORCID ID: orcid.org/0000-0002-2163-6564 Received: 27.11.2020 Accepted: 03.02.2021

Cite this article as: Gök ÇC, Kılıçlar T, Can E, Hamilçıkan Ş. Arthrotomy and Washing Procedure for Neonatal Bacterial Arthritis in a Series of Cases. Bagcilar Med Bull 2021;6(2):216-219

๑) Copyright 2021 by the Health Sciences University Turkey, Bagcilar Training and Research Hospital Bagcilar Medical Bulletin published by Galenos Publishing House. 
mother after a full physical examination was performed. On follow-up, respiratory distress was detected by the attending physician, and the patient was admitted to neonatal intensive care unit (NICU). On the $2^{\text {nd }}$ day of the admission, C-reactive protein (CRP) level was significantly increased to $84 \mathrm{mg} / \mathrm{dL}$. On the sixth day, a limited range of motion and $2 \times 2$ centimeters sized swelling on the front medial side of the right elbow was detected. In the control laboratory analysis, CRP and erythrocyte sedimentation rate (ESR) were $42 \mathrm{mg} / \mathrm{dL}$ and $32 \mathrm{~mm} / \mathrm{h}$, respectively. Diagnostic arthrotomy was performed and it showed no collection of fluid in the joint space. Two days later, arthrocentesis was performed and joint aspiration fluid showed no sign of infection. After the patient completed his 14-day antibiotic regimen for sepsis, follow-up X-ray images were taken and they revealed callus formation (Figure 1,2). Eventually, the neonate was diagnosed with distal humeral epiphysis separation fracture.

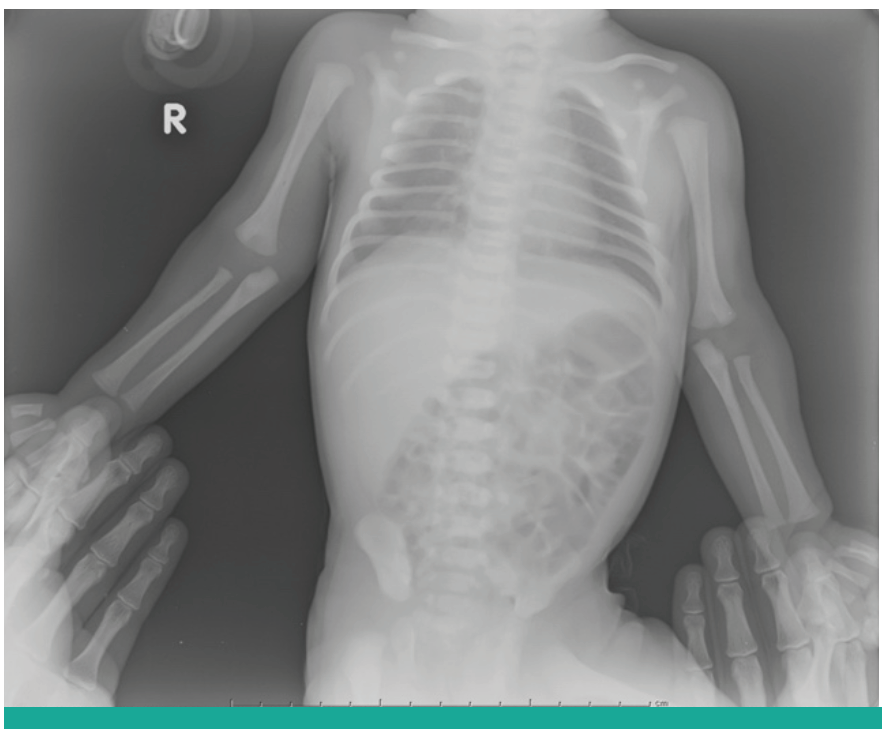

Figure 1. Radiographs of the right elbow

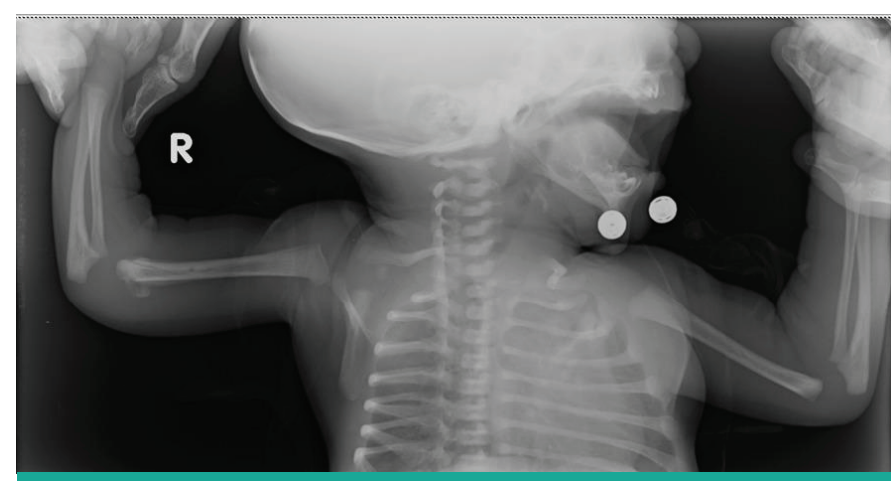

Figure 2. Radiograph at 3 weeks showing sufficient callus formation

\section{Case 2}

A 3.450 -g female neonate was born by vaginal delivery at 40 weeks of gestation to a 32-year-old gravida 4 mother. On the postnatal $10^{\text {th }}$ day, she was admitted to the hospital for crying during diaper changing and her mother realized a decrease in right leg movements. Physical examination revealed that the newborn was grimacing during the right hip joint movements. There was no swelling or the redness of the joint. Laboratory analysis revealed CRP and ESR values as $58 \mathrm{mg} / \mathrm{dL}$ and $28 \mathrm{~mm} / \mathrm{h}$, respectively. Diagnostic arthrotomy showed a collection of fluid in the joint space and the joint was irrigated. Arthrocentesis was performed and aspiration fluid showed signs of infection. S. aureus was obtained from the synovial culture specimen.

\section{Case 3}

A 3.350-g female neonate was born by vaginal delivery at 38 weeks of gestation to a 26 -year-old gravida 2 mother. On the postnatal $20^{\text {th }}$ day, she was admitted to the hospital for crying and restlessness. Physical examination revealed crying and increased restlessness when she moved the left hip joint. There was no swelling or redness by inspection. Laboratory analysis revealed CRP and ESR values as 52 $\mathrm{mg} / \mathrm{dL}$ and $45 \mathrm{~mm} / \mathrm{h}$, respectively. Diagnostic arthrotomy showed a collection of fluid in the joint space and the joint was irrigated. Arthrocentesis was performed and aspiration fluid showed signs of infection. S. agalactia was obtained from the the synovial culture and hemoculture specimen.

\section{Discussion}

$\mathrm{SA}$ is difficult to diagnose in patients younger than 3 months; even more difficult to diagnose in neonates because of the paucity of signs and symptoms. There is a lack of research guiding physicians as to which variables about irrigation and debridement in the management of pediatric SA (3).

Neonatal infections are unique to several forms as they are transmitted from mother to the fetus or newborn infant by diverse modes and neonates are less capable of responding to infection because of one or more immune deficiencies. In the descriptive study of Sreenivas et al. (4), 29 neonates presenting to the department of orthopaedics with acute SA were investigated. It was seen that the mean age of presentation were 23.8 days in their study, and there was female predominance. In the same study, it was also shown prematurity and anemia still appeared to be important risk factors for neonatal SA (4). Hip and knee joints are commonly affected in other studies $(5,6)$. 
Female gender was predominant in our cases. The median application time of the cases was determined as 8.6 days. The joint regions identified in our cases were the elbow and hip joints, respectively. However, none of our cases were preterm newborns.

The goals of treatment include sterilization and decompression of the joint space and removal of inflammatory debris to relieve pain and prevent deformity or functional sequel (7). Joint arthrotomy and washing procedures were performed in our cases, and then the treatment was continued with antibiotics. All cases were followed closely in the NICU.

Medical treatment was administered for 21 days with the recommended dose and dose range suitable for SA. The results of the blood culture were asked daily to ensure proper antibiotic selection. Due to the increase in CRP and ESR levels in a case, osteomyelitis was suspected and a magnetic resonance imaging (MRI) examination was performed. According to MRI results, the patient was diagnosed with osteomyelitis and the treatment was planned to be extended to 9 weeks. All patients were monitored closely during the treatment for ESR and acute phase reactants.

Arthrotomy and the open washout therefore remain the treatment of a choice to clear the microbial load from the joint (8). Although drainage and antimicrobial therapy are well-established cornerstones of therapy for bacterial arthritis, there are little evidence for controlled trials to guide decisions on the optimal procedure for drainage or the choice, route, or duration of antimicrobial therapy $(8,9)$. All aspirated materials should be sent to the laboratory and bacteriological examination. The presence of bacteria confirms the diagnosis of osteoarthritis. However, bacterial culture negative finding does not exclude infection $(10,11)$. S. aureus was obtained in synovial culture in only one of the cases and $S$. agalactiae was obtained in both of hemoculture and synovial cultures in one of them.

For possible complications in the postoperative period, 8-week follow-ups were scheduled. Patients continued the antibiotic treatment because of $S$. agalactia growth of both cultures. The initial total treatment time was 6 weeks for both babies. In the third case, total therapy was extended up to 9 weeks because the patient was additionally diagnosed with osteomyelitis. Hip dislocation as a procedure-related complication was observed in one of the cases. Routine use of open arthrotomy and washout therapy for SA in the newborn period should be evaluated for short and long term complications with comprehensive studies. However, this morality may be a suitable method of this period for the treatment of SA.

\section{Conclusion}

We have evaluated that arthrotomy and washing treatment can be applied in neonatal SA cases and complication rate of the procedure is similar to that of non-surgical methods.

\section{Acknowledgement}

We would like to thank the valuable consultants of the clinics of orthopedics and anesthesiology at our hospital.

\section{Ethic}

Informed Consent: We obtained consent from the families of the cases.

Peer-review: Internally peer-reviewed.

\section{Authorship Contributions}

Concept:Ç.C.G., T.K., Design: Ç.C.G., T.K., Data Collection or Processing: T.K., Ş.H., Analysis or Interpretation: T.K., Ş.H., Literature Search: Ç.C.G., T.K., E.C., Ş.H., Writing: Ç.C.G., T.K., E.C., S..H.

Conflict of Interest: No conflict of interest was declared by the authors.

Financial Disclosure: The authors declared that this study received no financial support.

\section{References}

1. Stans AA. Osteomyelitis and septic arthritis. In: Lovell and winter's pediatric orthopaedics. 6th ed. Morrissy RT, Weinstein SL (eds). Philadelphia: Lippincott Williams \& Wilkins; 2006:440.

2. Belthur MV, Palazzi DL, Miller JA, Phillips WA, Weinberg J. A clinical analysis of shoulder and hip joint infections in children. J Pediatr Orthop 2009;29(7):828-833.

3. Gatto A, Lazzareschi I, Onesimo R, Iannotta R, Rigante D, Capossela L, et al. Short therapy in a septic arthritis of the neonatal hip. Pediatr Rep 2019;11(3):8161.

4. Sreenivas T, Nataraj AR, Kumar A, Menon J. Neonatal septic arthritis in a tertiary care hospital: a descriptive study. Eur J Orthop Surg Traumatol 2016;26(5):477-481.

5. Halder D, Seng QB, Malik AS, Choo KE. Neonatal septic arthritis. Southeast Asian J Trop Med Public Health 1996;27(3):600-605.

6. Narang A, Mukhopadhyay K, Kumar P, Bhakoo ON. Bone and joint infection in neonates. Indian J Pediatr 1998;65(3):461-464.

7. Gutierrez K. Infectious and inflammatory arthritis. In: Principles and practice of pediatric infectious diseases, 4th ed. Long SS, Pickering LK, Prober CG (editors), Edinburgh: Elsevier Saunders; 2012:477. 
8. Kang SN, Sanghera T, Mangwani J, Paterson JM, Ramachandran $\mathrm{M}$. The management of septic arthritis in children: systematic review of the English language literature. J Bone Joint Surg $\mathrm{Br}$ 2009;91(9):1127-1133.

9. Mathews CJ, Coakley G. Septic arthritis: current diagnostic and therapeutic algorithm. Curr Opin Rheumatol 2008;20(4):457-462.
10. Sahu RL, Sikdar J. Childhood osteomyelitis with septic arthritis: a case report and review of literature. J Orthop 2010;62(1):37-39.

11. De Boeck H. Osteomyelitis and septic arthritis in children. Acta Orthop Belg 2005;71(5):505-515. 